mentary on the visit, for Dr. Zeffert described and demonstrated many types of plugs, sockets, terminal blocks and cables. The main run of lectures was continued on the next day with one on a.c. machines by W. Philipp (Rotax, Ltd.), who discussed the problems of alternator design, both for the long speed-range machines now in use and for the constant-speed machines which will be required when a constant-speed drive, taken either from an enginedriven hydraulic gear or from a separate turbine, becomes available; he also spoke on conversion equipmont, using invertors, rotary transformer or motor-alternators, and on induction motors. From machines the programme of the course turned to system operation and protection; in which $\mathrm{K}$. J. Payne (British Thomson-Houston Co., Coventry) considered power system maintenance, servicing the system or correcting faults being, of course, impossible during actual operational use. After a general discussion on the limits of operation of the components of a typical system and their effects on system performance, and also protection techniques, Mr. Payne described the transient behaviour of inverters and motors and the effects of electrical and mechanical shock loads. The theme of A. Grieve's (British Thomson-Houston Co., Coventry) lecture was switchgear, the factors involved in the design of switches, and the limitations imposed on performance by the fundamental properties of the matcrials and of the environment in which they are to operate ; in discussing the characteristics required of a circuit breaker, he said that protection against most forms of fault can be incorporated in any unit of switchgear.

In the concluding survey, in which he discussed future trends, S. F. Follett (Ministry of Supply) stated that future aircraft will fly faster and higher, so that environmental changes will most influence future practice; he felt that the need for reliability should be stressed, and that reliability should bo proved on life-tests which approximate to aircraft conditions and allow for the effect of vibration.

\section{MARINE BIOLOGY IN LATIN AMERICA}

$\mathrm{D}$

URING September 15-17 a group of Latin American specialists in marine biology met in Concepción (Chile) in order to study the possibility of establishing an international network of marine biologieal laboratories in Latin America and other ways of facilitating the collaboration in this field among the Latin American countries. The meeting was convoked by the Unesco Science Co-operation Office for Latin America and was a sequel to the recommendations for setting up international and regional laboratories made at a meeting held in Montevideo in 1952 upon the initiative of the Unesco Office (see Nature, 170,$605 ; 1952$ ). The scientists attending the meeting were from the Argentine, Brazil, Chile, Cuba, Mexico, Peru, Venezuela and Uruguay, The Regional Office in Santiago de Chile of the United Nations Food and Agriculture Organization collaborated in arranging the meoting.

After studying the present situation of research in marine biology in Latin America and its future possibilities, the delegates entered on an extensive discussion about the possibilities and ways of establishing an international network of laboratories. It was unanimously decided to create immediately under the auspices of the Unesco Science Co-operation Office a Latin American Committee in order to co-ordinate and facilitate the research work in marine biology. The Committee would remain in office until a permanent organization had been set up. The meeting requested the Unesco Office to prepare $a$ draft convention for an international network of laboratories and convoke a meeting of official delegates in order to establish the corresponding organization.

The meeting also studied what other steps could bo taken immediately pending the realization of the more far-reaching recommendations, in order to promote research in marine biology, and advised the Unesco Office that two training-courses on the methodology of marine biology research and a symposium on plankton should be organized in 1955 . It was also recommended that the Marine Biology Journal, produced by the Montemar Station in. Chile, should be widened in scope with a Latin American editorial board.

The Brazilian representatives to the meeting have been duly authorized by the Governor of the State of São Paulo to put at the disposal of the Unesco Science Co-operation Office for international research work the complete network of marine biological laboratories and stations and research vessels of the State of São Paulo. 'This offer will make it possible to initiate shortly international research and training programmes in marine biology under the auspices of the Unesco Office.

\section{UNITED NATIONS ORGANIZATION}

\section{ANNUAL REPORT OF THE SECRETARY- GENERAL FOR 1953-54}

$T$

HE ninth annual report of the Secretary-General of the United Nations to the Member States on the work of the Organization during July 1, 1953June 30, 1954* is not an encouraging document. It gives a picture of diversity of effort which closely matches that to be found in the reports on the work of the League of Nations, and, as with that organization, it is in the technical fields that progress is most marked. Filsewhere, and above all in the political field, the gap between purpose and achieve. ment is wide; nor does it appear that all Member States are coneerned to advance the declared purposes of the United Nations. The Secretary-General comments on the need for a careful balance in the development of regional arrangements outside the framework of the United Nations. Choice of such arrangements for the maintenance of peace should not be permitted to cast doubt on the ultimate responsibility of the United Nations, or to impair the right of a Member State to a hearing under the Charter.

Referring to the lack of progress in disarmament, the Secretary-General comments on the potentialities of the development of an international partnership, open to all nations, in the use of atomic energy for peaceful purposes, especially for the economically

* United Nations. Annual Report of the Secretary-General on the Work of the Organization, 1 July 1953-30 June 1954. (Genera Assembly-Official Records: Ninth Session. Supplement No. 1 (A/2663).) Pp. xv +120. (New York: United Nations; London H.M.S.O., 1954.) 1.25 dollars; 98 .; 5 Swiss francs. 